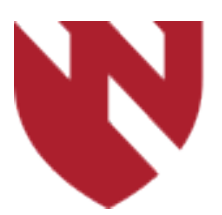

September 2020

\title{
Vitamin Deficiencies Are Extremely Common in Parkinson's Disease: A Case for Routine Screening
}

\author{
Erin Smith \\ University of Nebraska Medical Center \\ Jenna Paseka \\ University of Nebraska Medical Center \\ Danish Bhatti \\ University of Nebraska Medical Center \\ Diego R. Torres-Russotto \\ University of Nebraska Medical Center \\ John M. Bertoni \\ University of Nebraska Medical Center
}

Tell us how you used this information in this short survey.

Follow this and additional works at: https://digitalcommons.unmc.edu/gmerj

Part of the Higher Education Commons, and the Medicine and Health Sciences Commons

\section{Recommended Citation}

Smith, E., Paseka, J., Bhatti, D., Torres-Russotto, D. R., , Bertoni, J. M. Vitamin Deficiencies Are Extremely Common in Parkinson's Disease: A Case for Routine Screening. Graduate Medical Education Research Journal. 2020 Sep 29; 2(1).

https://digitalcommons.unmc.edu/gmerj/vol2/iss1/82

This Conference Proceeding is brought to you for free and open access by DigitalCommons@UNMC. It has been accepted for inclusion in Graduate Medical Education Research Journal by an authorized editor of DigitalCommons@UNMC.For more information, please contact digitalcommons@unmc.edu. 


\section{Vitamin Deficiencies Are Extremely Common in Parkinson's Disease: A Case for}

Routine Screening

\section{Creative Commons License}

\section{(c) (1) $\Theta(9$}

This work is licensed under a Creative Commons Attribution-Noncommercial-No Derivative Works 4.0 License. 
with PD developed acute confusion and visual hallucinations of butterflies ascribed to PD. She was considered for discharge until a dietary history revealed that a typical meal was diet soda and white bread. Serum B1 (49 nmol/L), B6 (<5.0 nmol/L), and folate $(5.4 \mathrm{ng} / \mathrm{mL})$ were low. Confusion and hallucinations resolved three days after replacement. Case 3 This 46-year-old policeman with PD presented for a second opinion in the Comprehensive PD Clinic. He complained of trouble walking and forgetfulness thought related to his PD. B12 was low $(176 \mathrm{pg} / \mathrm{mL})$ and normalized with replacement. Symptoms resolved within eight weeks.

Conclusion: Common symptoms of PD including gait problems, cognitive impairment, hallucinations, and sensory disturbances can be caused by vitamin deficiencies and are easily correctable. We are currently collecting nutritional data on our PD patients for future studies.

https://doi.org/10.32873/unmc.dc.gmerj.2.1.079

\section{Vitamin Deficiencies Are Extremely Common in Parkinson's Disease: A Case for Routine Screening Erin L. Smith', Jenna Paseka', Danish Bhatti', Diego R. Torres-Russotto', John M. Bertoni² \\ ${ }^{1}$ University of Nebraska Medical Center, Department of Neurological Sciences, Division of Movement Disorders \\ ${ }^{2}$ University of Nebraska Medical Center, Department of Neurological Sciences}

Mentor: John M. Bertoni

Program: Neurological Sciences, Division of Movement Disorders

Type: Original Research

Background: In this study we assess vitamin deficiencies in Parkinson's disease (PD) and their impact on disease characteristics and common clinical assessments.

Methods: 118 patients from our PD clinic underwent serum testing for thiamine (B1), pyridoxine (B6), cobalamin (B12) and 25-hydroxy cholecalciferol (D3). We compared age, BMI, disease duration, United Parkinson's Disease Rating Scale (UPDRS), Mini Mental Status Examination (MMSE), levodopa equivalent daily dose (LEDD), and reported falls between those with and without vitamin deficiencies. Statistical analyses included a nonparametric Wilcoxon twosample test and nonparametric Pearson and Spearman correlations.

Results: In total, 66 patients $(56 \%)$ were deficient in one vitamin, and 24 in two or more $(\mathrm{B} 1=6, \mathrm{~B} 6=26, \mathrm{~B} 12=44$, and $\mathrm{D} 3$ $=24)$. Average UPDRS score was 35 with average disease duration of 7 years for both groups. LEDD for deficient patients was higher $(712 \mathrm{mg}$ ) compared to the normal group (594 mg), though not statistically significant $(\mathrm{p}=0.11)$. There was a trend for older age in the deficient group (73 vs 69.5 years; $\mathrm{p}=0.093$ ). Both groups had similar MMSE scores and report of falls. There were no linear correlations between vitamin levels and age, BMI, disease duration, UPDRS, MMSE, or LEDD.

\section{Models of Pediatric Asthma Care Alamelu Udayappan ${ }^{1}$, Chad Abersch ${ }^{2}$}

${ }^{1}$ University of Nebraska Medical Center, Department of Pediatrics

${ }^{2}$ University of Nebraska Medical Center, CityMatCH

\section{Mentor: Chad Abersch}

Program: Pediatrics

Type: Review/Meta-analysis

Background: Asthma exacerbation is a leading cause of emergency department visits and one of the top indications for hospitalization in children. Not only does this burden the medical care system with accruing costs and resources, these exacerbations are highly preventable given a strong medical home and a practical model of pediatric asthma care. Our aim was to perform a systemic review of literature to evaluate the existent models of pediatric asthma care with clinical and public health outcomes.

Methods: The Up to Date, Cochrane Library, and PubMed databases were queried using the search terms "Models of Pediatric Asthma Care". We included all original, full-text abstracts published after 2010. We excluded abstracts pertaining to novel agents in treatment, ED/inpatient management, schoolbased protocols, complementary/alternative medication, environmental and epigenetic factors.

Results: The proposed models in literature are as follows:

1. Subgroup Analyses from the Prompting Asthma Intervention in RochesterUniting Parents and Providers Trial (Goldstein et all, 2018).

2. Children's Hospital Boston Community Asthma Initiative (Sommer et all, 2011).

3. Medical Home Model (Rojanasarot et all, 2018).
Conclusion: Our preliminary data suggest that although vitamin deficiencies were present in $56 \%$ of our PD patients, there was not a strong correlation between serum levels and objective clinical measurements. Sample size limited statistical power and we will repeat analyses as more patients are enrolled. There are many other objective measures that can be included in future studies.

https://doi.org/10.32873/unmc.dc.gmerj.2.1.080

4. Ensemble Learning Model (Khasha R et all, 2019).

5. Practice Organization Model (Ruffner MA et all, 2018).

Conclusion: Asthma continues to be a major public health problem despite novel treatment agents and guideline-based management. An ideal theoretical model would include a) family educational programs/community resources, b) severity/control assessment, d)ensuring access of medication/ insurance coverage, e) addressing environmental triggers, f)frequent follow up care for susceptible children, g) addressing co-morbid conditions, and h) implementing legislative policy change.

https://doi.org/10.32873/unmc.dc.gmerj.2.1.082 